\title{
Latent Fundamentals Arbitrage with a Mixed Effects Factor Model
}

(Arbitragem com Fundamentos Latentes em um Modelo Fatorial de Efeitos

Mistos)

\author{
Andrei Salem Gonçalves* \\ Robert Aldo Iquiapaza** \\ Aureliano Angel Bressan***
}

\begin{abstract}
We propose a single-factor mixed effects panel data model to create an arbitrage portfolio that identifies differences in firm-level latent fundamentals. Furthermore, we show that even though the characteristics that affect returns are unknown variables, it is possible to identify the strength of the combination of these latent fundamentals for each stock by following a simple approach using historical data. As a result, a trading strategy that bought the stocks with the best fundamentals (strong fundamentals portfolio) and sold the stocks with the worst ones (weak fundamentals portfolio) realized significant risk-adjusted returns in the U.S. market for the period between July 1986 and June 2008. To ensure robustness, we performed sub period and seasonal analyses and adjusted for trading costs and we found further empirical evidence that using a simple investment rule, that identified these latent fundamentals from the structure of past returns, can lead to profit.
\end{abstract}

Keywords: arbitrage; factor models; mixed effects.

JEL codes: G11; G12.

\section{Resumo}

Neste artigo, propomos um modelo de fator único com efeitos mistos para dados em painel de modo a criar uma carteira de arbitragem que identifica diferenças de fundamentos latentes ao nível da firma. Com base neste modelo, é possível verificar que, embora as características que afetam os retornos são variáveis desconhecidas, é possível identificar a força da combinação destes fundamentos latentes para cada empresa, seguindo uma abordagem simples com dados históricos. Como resultado, uma estratégia de arbitragem que comprou as ações com os melhores fundamentos (carteira de fundamentos fortes) e vendeu as ações

Submitted 17 April 2012. Reformulated 7 July 2012. Accepted 1 August 2012. Published online 15 October 2012. The article was double blind refereed and evaluated by the editor. Supervising editor: Ricardo P. C. Leal. The authors gratefully acknowledge the financial support from the Brazilian National Scientific Research Council (CNPq) and the language help from Elsevier Language Editing service.

*Wisconsin School of Business, University of Wisconsin-Madison, USA. E-mail: agoncalves $₫$ wisc.edu

**CEPEAD/Faculdade de Ciências Econômicas/UFMG, MG, Brasil. E-mail: riquiapaza@ gmail.com ufmg.br

***CEPEAD/Faculdade de Ciências Econômicas/UFMG, MG, Brasil. E-mail: aureliano@

\footnotetext{
Rev. Bras. Finanças, Rio de Janeiro, Vol. 10, No. 3, September 2012, pp. 317-335 
com os piores fundamentos (carteira com fundamentos fracos) apresentou retornos ajustados ao risco significativos no mercado dos EUA para o período entre Julho de 1986 e Junho de 2008. Para assegurar a robustez, realizamos análises subperíodo, sazonais e ajustamos para os custos de negociação, reforçando as evidências empíricas de que, usando uma regra simples investimento, que identificou esses fundamentos latentes na estrutura de retornos passados, a estratégia apresenta resultados positivos.

Palavras-chave: arbitragem; modelos fatoriais; efeitos mistos.

\section{Introduction}

One of the major issues in investment management is the quest for an efficient securities selection criterion that can distinguish prospective winners from losers. The basic principle is grounded in two main conjectures. First, even if one believes that the market is efficient in the short or long run, there is no reason to believe that instant market quotes reflect long-run value in the short run (Black 1986). Second, market microstructure, liquidity and behaviorist explanations suggest that, at any given time, prices may be noisy and returns skewed.

The value and growth investing principles are based on well-known deviations that persist in the U.S. as well as in international markets; attracting a great deal of academic empirical research (Chan \& Lakonishok, 2004). There is vast empirical evidence (Fama \& French, 1992, 1996, 1998, Lakonishok et al., 1994) suggesting that, on average, value stocks outperform glamour (growth) stocks. Nevertheless, the explanation for the Value Premium anomaly in stock returns is still debated. Fama \& French $(1992,1996)$ argue that the market is efficient and that value investing has better performance because value stocks are riskier. Another explanation is offered by Lakonishok et al. (1994), who explain the value premium anomaly by arguing that investors' cognitive biases and the agency costs of professional investment lead individuals and institutional investors to prefer growth stocks and dislike value stocks.

There are other significant aggregate factors associated with deviations from the CAPM equilibrium model, such as firm size, liquidity, cash flows, dividend yields, earnings yields, volatility, accruals, etc. (Fama \& French, 1992, 1996, Acharya \& Pedersen, 2005, Liu, 2006, Ang et al., 2006, Ang \& Bekaert, 2007, Hirshleifer et al., 2009, Kang et al., 2010). However, Subrahmanyam (2010) stated that predictive variables stem from informal arguments, alternative tests of risk-return models, behavioral biases, and frictions, such as limited arbitrage and leverage controls. This is particularly true for sophisticated professional investors (Stein, 2009). According to Subrahmanyam (2010, p. 27), in the last twenty five years "more than fifty variables have been used to predict returns".

This paper does not aim to explain why these deviations persist or what the specific relevant variables are. Instead, the aim is to show that it is possible to profit from the deviations by estimating a combination of the unknown relevant variables.

The usual way to take advantage of persistent deviations, and thus to identify 
prospective winners and losers, is to sort the stocks for a particular characteristic. For example, to identify growth and value stocks, it is necessary to estimate several indicators or fundamentals, such as the earnings/price ratio (EP) and the book-to-market ratio (BTM). Growth stocks usually have low EP and BTM ratios, meaning that they are relatively high-priced in comparison with the companies' net asset values. On the other hand, value stocks have relatively high EP and BTM ratios. Other firm characteristics, such as size, dividend yield, and liquidity, which contribute to the explanation of the cross section of returns, are similarly identified.

There are also more complex procedures that identify prospective winners and losers. Some researchers suggest the use of structural VAR (vector autoregression) and/or VEC (vector error correction) models that include macroeconomic variables and/or fundamentals, such as growth rates of industrial production and stock prices (Binswanger, 2004, Louis \& Eldomiaty, 2010, Chou et al., 2011).

In this paper, we take an alternative approach to identify prospective winners. Our aim is to show that it is possible to take advantage of any premium arbitrage opportunity by identifying the firm's latent fundamentals based on the correlation structure of the stocks' past returns in a single mixed effects panel data factor model. In this way, we also propose an answer to Subrahmanyam's (2010: p27) remark, when he argues that "more needs to be done to consider the correlation structure amongst the variables, use a comprehensive set of controls, and discern whether the results survive simple variations in methodology".

We found empirical evidence that a zero net investment portfolio (i.e., an arbitrage portfolio), structured with a long position in a portfolio composed of stocks with the best combination of the $N$ latent fundamental factors (the "strong fundamentals portfolio") and a short position in a portfolio composed of stocks with the worst combination of the $N$ fundamental factors (the "weak fundamentals portfolio"), generated positive and statistically significant risk-adjusted returns, considering the Carhart (1997) 4-factor model.

The remainder of this paper is organized as follows. Section 2 describes the theoretical background to identify stocks with the strongest and the weakest firmlevel latent fundamentals. Section 3 describes the data and presents the statistical model used to perform the analysis, as well as the portfolio's formation procedure. Section 4 reports the general results with a sub period and seasonal analysis of the strategy and reports the results adjusted for trading costs. Section 5 concludes.

\section{Theoretical Background}

\subsection{Preliminaries}

The structure of stock returns was first studied by Markowitz (1952) through the mean-variance framework, which represented the theoretical basis for the Factor Models and the well-known Capital Asset Pricing Model (CAPM) that were proposed by Sharpe (1964), Lintner (1965) and Mossin (1966).

According to Bodie et al. (2001), the single-factor model can be expressed as 
follows:

$$
r_{i, t}=E\left(r_{i}\right)+\beta_{i} M_{t}+\epsilon_{i, t}
$$

where $r_{i, t}$ is the return on stock $i$ at time $t, E\left(r_{i}\right)$ is the expected return of stock $i$ unconditioned on time, $M_{t}$ is the value of the market factor that affects all securities at time $t, \beta_{i}$ is the sensitivity of stock $i$ to that factor and $\epsilon_{i, t}$ is the idiosyncratic return of stock $i$ at time $t$.

From Equation 1, it can be inferred that $M$ captures the effects of unanticipated market movements and $\epsilon$ expresses the return related to the firm-level characteristics. The expectations for both market and firm-level innovations are equal to zero. Furthermore, Sharpe (1963) presented the single-index model, which is a particular restriction of the single-factor model:

$$
r_{i, t}=\left(\alpha_{i}+r_{f}\right)+\beta_{i}\left(r_{M, t}-r_{f}\right)+\epsilon_{i, t}
$$

where $r_{f}$ is the return on the economy risk-free asset, and $r_{M, t}$ is the return on the market portfolio at time $t$.

In Equation 2, $\left(r_{M, t}-r_{f}\right)$ is the factor that expresses unanticipated market surprises. As $E\left(r_{M, t}-r_{f}\right)$ is not necessarily equal to zero, the intercept of the model, $\left(\alpha_{i}+r_{f}\right)$, is not the expected return of stock $i$ unconditioned on time as in the single-factor model. As $\alpha_{i}$ is the market risk (sensibility) of stock $i$ and $r_{f}$ can be obtained by a risk-free investment, $\alpha_{i}$ can be viewed as the return above the risk or the risk-adjusted return for the stock $i$.

Given specific assumptions about the economy, the CAPM general equilibrium predicts that the risk premium on individual assets, $E\left(r_{i, t}-r_{f}\right)$, will be proportional to the risk premium on the market portfolio, $E\left(r_{M, t}-r_{f}\right)$, and that the securities' market sensibility $\left(\beta_{i}\right)$ will be as follows:

$$
\left\{\begin{array}{l}
(i) r_{i, t}=r_{f}+\beta_{i}\left(r_{M, t}-r_{f}\right)+\epsilon_{i, t} \\
(i i) E\left(r_{i, t}\right)-r_{f}=\beta_{i}\left[E\left(r_{M, t}\right)-r_{f}\right]
\end{array}\right.
$$

According to the CAPM, $\epsilon_{i}$ is the idiosyncratic return of firm $i$, and it is not related to any risk source. In addition, $E\left(\epsilon_{i}\right)=0$ and $E\left[\epsilon_{i} \mid\left(r_{M, t}-r_{f}\right)\right]=0$. Furthermore, comparing equations 2 and 3, the CAPM predicts that $\alpha_{i}$ should be zero for all assets. As $\alpha_{i}$ is the risk-adjusted return for stock $i$, the CAPM implies that no asset can generate returns above its exposure to market risk. As the CAPM is a model of expected returns, it allows the stocks' realized returns to present risk-adjusted returns that are different from zero, but it also states that the expected risk-adjusted returns of different stocks are random variables with mean zero.

Although the CAPM is widely used in security analysis, the empirical evidence demonstrates that it suffers from serious problems that limit its applicability (Friend \& Blume, 1970, Jensen et al., 1972, Elton et al., 1993, Jagannathan \& 
McGrattan, 1995, Fama \& French, 2004)[among others]. As an alternative, Ross (1976) proposed the Arbitrage Pricing Theory (APT). The APT promises results similar to the CAPM, ${ }^{1}$ but implies that the risk-adjusted return must be equal to zero if and only if the factor model used is an unrestricted multifactor model for the structure of stock returns.

In this context, some of the firm's characteristics, such as size and value, play an important role in determining the structure of its stock returns. As a consequence, the 3-factor model was proposed by Fama \& French (1993) to account for the effects of value and size-related variables that affect returns:

$$
r_{i, t}-r_{f}=\beta_{i}\left(r_{M, t}-r_{f}\right)+S_{i} S M B_{t}+H_{i} H M L_{t}+\epsilon_{i, t}
$$

where $S M B_{t}$ is the return at time $t$ of a portfolio composed of a long position in the biggest companies and a short position in the smallest ones (size factor), $H M L_{t}$ is the return at time $t$ of a portfolio composed of a long position in the highest value companies and a short position in the lowest value ones (value factor) and $S_{i}$ and $H_{i}$ are the sensibility of stock $i$ to the size and value factors, respectively.

According to tests performed by Fama \& French (1996), the 3-factor model explains most of the asset pricing anomalies described in the literature aside from the momentum effect proposed by Jegadeesh \& Titman (1993). As a consequence, the 4-factor model was introduced by Carhart (1997), and it is essentially the 3factor model with the addition of the momentum factor:

$$
r_{i, t}-r_{f}=\beta_{i}\left(r_{M, t}-r_{f}\right)+S_{i} S M B_{t}+H_{i} H M L_{t}+U_{i} U M D_{t}+\epsilon_{i, t}
$$

where $U M D_{t}$ is the return at time $t$ of a portfolio composed by a long position in the winners (stocks with the highest past returns) and a short position in the losers (stocks with the lowest past returns), and $U_{i}$ is the sensibility of stock $i$ to this momentum factor.

More recently, other anomalies that represent important factors for the structure of stock returns were presented in the literature, such as the liquidity factor (Acharya \& Pedersen, 2005, Liu, 2006) and the exposure to the aggregated volatility (Ang et al., 2006). As can be seen, empirical evidence in the literature provides several different asset pricing anomalies; to identify the factor model that explains the structure of stock returns, these anomalies must be counted as factors in addition to the market portfolio excess return.

We claim that one possible unrestricted model that explains the structure of stock returns will present $N+1$ different factors. ${ }^{2}$ One factor is a market portfolio factor that affects all assets, though in different intensities (alternative assets have

\footnotetext{
${ }^{1}$ Although more general since the driven risk factors are not specified by the model.

${ }^{2}$ There is no difference in the reasoning if we allow the number of factors to vary among the firms, so $N_{i}+1$
} 
different sensibilities to this factor), while the other $\mathrm{N}$ factors are firm-level latent fundamentals that comprise the "microeconomics" of firms. These firm-level latent fundamentals, in a panel data setting, correspond to the heterogeneity between these firms. We shall prove that, although the $\mathrm{N}$ firm-level factors are unknown, it is still possible to discover what stocks present the best and the worst combinations of the $\mathrm{N}$ latent fundamental factors by following a simple procedure.

\subsection{The model}

First, consider the following model:

$$
r_{i, t}=r_{f}+\beta_{i} M_{t}+\gamma_{i}+\omega_{i, t}
$$

where $M_{t}$ is the market factor at time $t, \gamma_{i}$ is the specific firm-level fundamental that exists but cannot be measured under the structure of the return of stock $r_{i, t}$ and $\omega_{i}$ represents the idiosyncratic return under the hypothesis that the model proposed in 6 is the unrestricted model.

Let us assume that the firm-level fundamental is the firm's size. Therefore, the influence of firms $i$ 's size in the structure of its returns is equal to $\gamma_{i}$. Now, let the following equation represent the real unrestricted factor model for the structure of stock returns:

$$
r_{i, t}=r_{f}+\beta_{i} M_{t}+\gamma_{1, i}+\gamma_{2, i}+\ldots+\gamma_{N, i}+\omega_{i, t}
$$

where $M_{t}$ is the market factor at time $t, \gamma_{k, i}$ is the influence of the k-th firm-level characteristic under the structure of returns and $\omega_{i}$ represents the real idiosyncratic return for the stock $i$ under the true unrestricted model for stock returns, such that $E\left(\omega_{i}\right)=0$ and $\operatorname{Var}\left(\omega_{i}\right)=\delta_{i}^{2}$

Also, consider that each $\gamma_{k, i}$ is related to a specific firm-level characteristic $X_{k}$. Then $\gamma_{k, i}$ can be viewed as the magnitude of the influence of characteristic $X_{k}$ on the structure of stock $i$ 's returns. As the firm's fundamentals are stable, at least in the short run, we consider that the parameters $\gamma_{k, i}$ are relatively stable through time and deterministic for a specific time span $t$.

In this setting, we maintain the original one risk factor model, or market model. Recently, Cohen et al. (2009), using cross-sectional tests, found that there exist specifications in which the differences in the relative price levels of individual stocks can be largely explained by their fundamental betas. For these authors, "the CAPM fails to explain the one-period expected returns on some dynamic trading strategies but, ..., gets stock prices and expected long-term returns approximately right" (p.2742). It is important not to relate the firm-level characteristics $X_{k}$ to aggregate risk factors, such as the size, value and/or momentum factors, which are already well-explored in the models presented in the literature. These aggregate risk factors are conceptually different from those in Equation 7, where the fundamentals indicate the influences of firm-level unobserved characteristics that do not change through time (in the short run). 
As the model proposed in Equation 7 is the unrestricted model for the structure of stock returns, its intercept is equal to zero. The expression $\beta_{i} \cdot M_{t}$ represents stock $i$ 's return, generated by its exposition to the market factor. Thus, $\beta_{i} \cdot M_{t}$ is the return related to the stock's market risk. The expression $\gamma_{1, i}+\gamma_{2,1}+\cdots+\gamma_{N, i}$ is the stock's return related to its own unobserved or latent fundamentals and, therefore, does not contribute as a risk factor to the structure of stock returns.

Now, let the market factor $M$ be the market excess return, and $\eta_{i}=\gamma_{1, i}+$ $\gamma_{2, i}+\cdots+\gamma_{N, i}$. Rewriting Equation 7, we have the following:

$$
r_{i, t}-r_{f}=\beta_{i}\left(r_{M, t}-r_{f}\right)+\eta_{i}+\omega_{i, t}
$$

As a consequence, $\eta_{i}$ is the $i-t h$ firm-level latent fundamentals' influence under the structure of its returns. Comparing Equation 8 to the single index model in Equation 2, we have $\eta_{i}=\alpha_{i}$, and thus, the CAPM predicts that $E\left(\eta_{i}\right)=0$. We do not rule this result out, but we take a different view. As $\eta_{i}$ represents firm $i$ 's latent fundamentals influence under the structure of stock $i$ 's returns, and because the firm's latent fundamentals are relatively stable over time, we have:

$$
\left\{\begin{array}{l}
(i) E\left(\eta_{i}\right)=0 \\
(i i) \operatorname{Var}\left(\eta_{i}\right)=v \\
(i i i) E\left(\eta_{i} \mid i\right) \neq 0 \\
(i v) \operatorname{Var}\left(\eta_{i} \mid i\right) \cong 0
\end{array}\right.
$$

Applying the Expectation and Variance operators to Equation 8, we obtain the following:

$$
\left\{\begin{array}{l}
E\left(r_{i, t}\right)=r_{f}+\beta_{i}\left[E\left(r_{M, t}\right)-r_{f}\right] \\
V A R\left(r_{i, t}\right)=\beta_{i}^{2} V A R\left(r_{M, t}\right)+v+V A R\left(\omega_{i, t}\right)
\end{array}\right.
$$

If we consider that $\epsilon_{i, t}=\eta_{i}+\omega_{i, t}$, then the results proposed in Equation 10 are the same basic results as the CAPM, and the idiosyncratic return for the CAPM model has two components: the real idiosyncratic return and the return related to the firm's own latent fundamentals.

As a consequence, now applying the conditional Expectation and Variance operators to Equation 8, we obtain the following:

$$
\left\{\begin{array}{l}
E\left(r_{i, t} \mid i\right)=r_{f}+\beta_{i}\left[E\left(r_{M, t}\right)-r_{f}\right]+E\left(\eta_{i} \mid i\right) \\
V A R\left(r_{i, t} \mid i\right)=\beta_{i}^{2} V A R\left(r_{M, t}\right)+V A R\left(\omega_{i, t} \mid i\right)
\end{array}\right.
$$

Observe that $\eta_{i}$ contributes to stock $i$ 's expected return, but it does not contribute to its volatility. Therefore, the higher the value of $E\left(\eta_{i} \mid i\right)$, the higher the firm's expected returns will be, due to their strong latent fundamentals. 
If our model's prediction in Equation 11 is valid, then a strategy that buys stocks from firms with the best (strongest) fundamentals - expressed by higher values of $\eta_{i}$ - and shorts those with the worst (weakest) fundamentals should generate positive and statistically significant risk-adjusted returns because these fundamentals are not related to any market risk source. In addition, because Equation 8 represents an unrestricted model for the structure of stocks' returns, a significant risk-adjusted return must be observed regardless of the factor model used to analyze the returns, as long as this factor model is not the unrestricted model itself.

\section{The Data}

\subsection{Data Collecting and Sampling}

This study considers monthly returns between July 1985 and June 2008. The statistical tests and performance measures were performed for the period of July 1986 to June 2008; this is defined as the sample period.

The sample study is composed of the 1,000 biggest U.S. companies ${ }^{3}$ for each year. The Center for Research in Security Prices (CRSP) Value Weighted Index and the Monthly Treasury Bill rate were used as proxies for the market portfolio and the risk-free rate, respectively.

The data set was obtained from three different databases. All of the information regarding stocks and indices was obtained from the CRSP monthly file database, while the monthly Treasury bill rate was collected from the Federal Reserve Bank interest rate database. The data used for the 4-Factor model employed in the analysis was obtained from Kenneth French's website. ${ }^{4}$

\subsection{Estimation procedures}

From the derivations in section 2.2, we have the model in Equation 8 as the unrestricted model for the structure of stock returns. We also demonstrated that higher values of $\eta_{i}$ imply stronger firm-level fundamentals for the $i$-th firm and, as a consequence, higher expected returns. However, because there are too many parameters to be estimated in Equation 8, there would be a high loss in terms of degrees of freedom. To manage that limitation, the following longitudinal one-factor model with mixed effects was used for the analysis and estimated by Restricted Maximum Likelihood: ${ }^{5}$

$$
r_{i, t}-r_{T B, t}=\beta\left(r_{C R S P, t}-r_{T B, t}\right)+b_{i}\left(r_{C R S P, t}-r_{T B, t}\right)+\eta_{i}+\omega_{i, t}
$$

where $r_{T B, t}$ is the Treasury bill rate at month $t, r_{C R S P, t}$ is the CRSP Value Weighted Index return at month $t, \beta$ is the model's fixed effect and $b_{i}$ and $\eta_{i}$ are

\footnotetext{
${ }^{3}$ The companies are ranked by their market cap (market cap $=$ number of shares outstanding times price per share) at the last trading day of May for each year.

${ }^{4}$ http://mba.tuck. dartmouth.edu/pages/faculty/ken.french/data\_library. htmlAvailable at 02/09/2010.

${ }^{5}$ For details about the longitudinal approach used, see Fitzmaurice et al. (2004).
} 
the model's random effects. In addition, we have that $\left(b_{i}, \eta_{i}\right) \sim N_{2}\left(0, \sum\right)$, where $\sum$ is the covariance matrix for the random effect coefficients. ${ }^{6}$ The sensitivity of stock $i$ to the market is given by $\beta+b_{i}$ and the firm-level latent fundamentals' influence on the structure of stock i's returns is $\eta_{i}$.

As of the first trading day for every $\mathrm{July}^{7}$ from 1986 to 2007, we estimated the model proposed in Equation 12 using the last 12 months' information. As the 1,000 biggest companies were evaluated at every end of May, we verified which of them were still being traded in the market on the first trading day of July of the same year, and those not traded were excluded from the analysis. ${ }^{8}$ Then we ranked the stocks in an ascending order by their firm-level fundamentals $\eta_{i}$ and constructed 10 equally weighted portfolios based on this ranking. The hundred lowest $\eta_{i}$ stocks formed portfolio 1 (the "weak fundamentals portfolio"), the next hundred formed portfolio 2 and so on up to portfolio 10 (the "strong fundamentals portfolio"). Portfolio 10 would be formed by less than 100 stocks, because some of the 1,000 stocks were not being traded any longer as of the July first trading day of the following year. ${ }^{9}$

In addition, a zero net investment portfolio (the "arbitrage portfolio") was created to take advantage of the differences in firm-level latent fundamentals, thereby taking a long position in the strong fundamentals portfolio and a short position in the weak fundamentals portfolio as of every July. To minimize trading costs, the portfolios were not rebalanced until the first trading day of July of the next year, when the analysis was performed again and the new portfolios were formed (i.e., we considered a one-year investment horizon).

The arbitrage portfolio does not present real percentage returns because there is no net investment. Consequently, to interpret the results we considered the returns per dollar long in this portfolio as the arbitrage portfolio returns. In addition, there are two arbitrary adequacy rules for the implementation of this strategy:

a) If a portfolio, at some point during the portfolio's investment horizon, contains a company that does not present information at that point, the stock is considered sold at exactly the last price available for the last trading day of the previous month and the funds are not reinvested until the next analysis date.

\footnotetext{
${ }^{6}$ The normality assumption here is imposed to simplify the estimation of the latent fundamentals parameters (which become the conditional modes of the random effects given the estimated fixed effects). However, it is important to note that there is no link with beliefs of normality of returns since the latent fundamentals parameters are only used to rank stocks, but no inference is performed based on their estimation.

${ }^{7}$ By composing the portfolios at July first trading day we avoid possible effects from financial statement disclosures.

${ }^{8}$ This was done for each year to assure the applicability of the strategy.

${ }^{9}$ During the analysis, the number of stocks in the strong portfolio ranged from 92 to 98.
} 
b) If a stock does not have any available information to perform the analysis for a specific month, then the observation of this stock for this specific month is dropped. ${ }^{10}$

\section{Estimation Results}

\subsection{Overall results}

The portfolios' results for the sample period are reported in Table 1. The average returns, risk premium, tracking error and risk-adjusted returns appear to grow according to the portfolio's firm-level fundamentals strength. In addition, the risk measures (CAPM Beta and Standard Deviation) follow a similar pattern, but both the weak and the strong portfolios present high-risk levels in comparison to the other portfolios. The strong fundamentals portfolio had a statistically superior variance to the weak portfolio $(F=2.31)$, in line with the explanation and results of Fama \& French $(1992,1993)$ and Petkova \& Zhang (2005).

The strong portfolio presented an average return and risk premium higher than the market and a market sensibility of 0.71 . This means that the strong portfolio's average return was above the market's return, and its market sensibility was lower than it was for the market portfolio itself.

Furthermore, the strong fundamentals portfolio's risk-adjusted return is positive and statistically significant, while the arbitrage portfolio has an average return, risk premium, and tracking error as well as risk-adjusted returns that are positive and statistically significant. Similarly, the results for the portfolio with weak fundamentals generated negative risk-adjusted returns. These results are in accordance with our model's theoretical background and, therefore, provide empirical evidence of its validity. They are also in line with the literature of market anomalies and abnormal returns Fama \& French (1992, 1998, 2006), Lakonishok et al. (1994), Sharma et al. (2008, among others). Moreover, the arbitrage portfolio's market sensibility was only 0.14 , which indicates a low level of market risk, as is expected given its composition (long and short positions in alternative portfolios). The arbitrage portfolio had an average monthly risk-adjusted return of $2.07 \%$ ( $27.87 \%$ annually). As a point of reference, this result is much more expressive than the expected value premium of $6.1 \%$ per annum found by Chen et al. (2008) for the period from 1945 to 2005.

\footnotetext{
${ }^{10}$ This rule was applied for a very insignificant number of observations.
} 
Table 1

Portfolios' results: sample period analysis, July 1986 to June 2008

\begin{tabular}{|c|c|c|c|c|c|c|}
\hline \multicolumn{7}{|c|}{$\begin{array}{l}\text { The portfolios are created every July first trading day according to the firms' fundamentals strength in the } \\
\text { previous } 12 \text { months, and the investment horizon is one year ahead. Monthly results are reported and refer } \\
\text { to the period between July } 1986 \text { and June } 2008(n=264) \text {; their } t \text {-statistics are reported in parenthesis. } \\
\text { The Risk Premium is the portfolio average excess return considering the risk-free rate, the Tracking Error is } \\
\text { the portfolio average excess return considering the market portfolio return and the risk-adjusted returns are } \\
\text { related to the } 4 \text {-factor model presented in Equation } 5 \text { and are robust to the presence of heteroskedasticity, } \\
\text { autocorrelation and outliers. }{ }^{11} \text { The CRSP Value Weighted Index and the Monthly Treasury Bill rate were } \\
\text { used as proxies for the market portfolio and the risk-free rate respectively. The arbitrage portfolio has value } \\
\text { zero every July } 1^{\text {st }} \text {, and therefore, we considered the returns per dollar long in this portfolio as its returns }\end{array}$} \\
\hline Portfolio & $\begin{array}{c}\text { Average } \\
\text { Return }\end{array}$ & $\begin{array}{c}\text { Risk } \\
\text { Premium }\end{array}$ & $\begin{array}{l}\text { Tracking } \\
\text { Error }\end{array}$ & $\begin{array}{l}\text { Risk-Adjusted } \\
\text { Return }\end{array}$ & $\begin{array}{l}\text { CAPM } \\
\text { Beta }\end{array}$ & $\begin{array}{c}\text { Standard } \\
\text { Deviation }\end{array}$ \\
\hline $\begin{array}{l}\text { Weak Fundamentals } \\
\text { Portfolio }\end{array}$ & $\begin{array}{l}-0.0007 \\
(-0.20) \\
\end{array}$ & $\begin{array}{c}-0.0044 \\
(-1.30) \\
\end{array}$ & $\begin{array}{l}-0.0097 \\
(-3.00) \\
\end{array}$ & $\begin{array}{c}-0.0052 \\
(-1.48) \\
\end{array}$ & 0.55 & 0.0542 \\
\hline Portfolio 2 & $\begin{array}{l}0.0059 \\
(2.36)\end{array}$ & $\begin{array}{l}0.0022 \\
(0.88)\end{array}$ & $\begin{array}{l}-0.0031 \\
(-1.23) \\
\end{array}$ & $\begin{array}{l}-0.0013 \\
(-0.49) \\
\end{array}$ & 0.48 & 0.0405 \\
\hline Portfolio 3 & $\begin{array}{l}0.0087 \\
(3.74) \\
\end{array}$ & $\begin{array}{l}0.0050 \\
(2.14)\end{array}$ & $\begin{array}{l}-0.0003 \\
(-0.14) \\
\end{array}$ & $\begin{array}{l}0.0005 \\
(0.22) \\
\end{array}$ & 0.47 & 0.0377 \\
\hline Portfolio 4 & $\begin{array}{l}0.0095 \\
(4.08) \\
\end{array}$ & $\begin{array}{l}0.0058 \\
(2.49) \\
\end{array}$ & $\begin{array}{l}0.0005 \\
(0.20) \\
\end{array}$ & $\begin{array}{l}0.0011 \\
(0.45) \\
\end{array}$ & 0.49 & 0.0378 \\
\hline Portfolio 5 & $\begin{array}{l}0.0113 \\
(4.79)\end{array}$ & $\begin{array}{l}0.0076 \\
(3.22)\end{array}$ & $\begin{array}{l}0.0023 \\
(0.97)\end{array}$ & $\begin{array}{l}0.0019 \\
(0.73)\end{array}$ & 0.49 & 0.0385 \\
\hline Portfolio 6 & $\begin{array}{l}0.0132 \\
(5.10)\end{array}$ & $\begin{array}{l}0.0095 \\
(3.66)\end{array}$ & $\begin{array}{l}0.0042 \\
(1.69)\end{array}$ & $\begin{array}{l}0.0024 \\
(0.78)\end{array}$ & 0.54 & 0.0420 \\
\hline Portfolio 7 & $\begin{array}{c}0.0148 \\
(5.37) \\
\end{array}$ & $\begin{array}{l}0.0111 \\
(4.02)\end{array}$ & $\begin{array}{l}0.0058 \\
(2.20) \\
\end{array}$ & $\begin{array}{c}0.0008 \\
(0.35) \\
\end{array}$ & 0.55 & 0.0449 \\
\hline Portfolio 8 & $\begin{array}{l}0.0167 \\
(5.62) \\
\end{array}$ & $\begin{array}{c}0.0130 \\
(4.37) \\
\end{array}$ & $\begin{array}{l}0.0077 \\
(2.76)\end{array}$ & $\begin{array}{l}0.0032 \\
(0.85) \\
\end{array}$ & 0.58 & 0.0483 \\
\hline Portfolio 9 & $\begin{array}{c}0.0216 \\
(6.40)\end{array}$ & $\begin{array}{l}0.0179 \\
(5.29) \\
\end{array}$ & $\begin{array}{l}0.0126 \\
(4.07)\end{array}$ & $\begin{array}{l}0.0037 \\
(1.13)\end{array}$ & 0.63 & 0.0550 \\
\hline $\begin{array}{l}\text { Strong Fundamentals } \\
\text { Portfolio }\end{array}$ & $\begin{array}{l}0.0312 \\
(6.15) \\
\end{array}$ & $\begin{array}{l}0.0275 \\
(5.42) \\
\end{array}$ & $\begin{array}{l}0.0222 \\
(4.66) \\
\end{array}$ & $\begin{array}{l}0.0084 \\
(2.25) \\
\end{array}$ & 0.71 & 0.0823 \\
\hline $\begin{array}{l}\text { Arbitrage Portfolio } \\
\text { Market }\end{array}$ & $\begin{array}{l}0.0311 \\
0.0090 \\
(3.36)\end{array}$ & $\begin{array}{l}0.0274 \\
0.0053 \\
(1.99)\end{array}$ & 0.0221 & 0.0207 & 0.14 & 0.0921 \\
\hline
\end{tabular}

From these results, we conclude that our approach allowed us to estimate the influence of the firm-level latent fundamentals of different stocks and that these fundamentals had a direct influence on the stocks' returns during the sample period. In addition, it was possible to obtain positive risk-adjusted returns in an arbitrage strategy by identifying and trading the strongest and weakest firm-level fundamentals for that period.

\subsection{Subperiod and seasonal analyses robustness checks}

To assure that our results were not conditioned to some sample-specific bias, we divided the sample period into five subperiods and performed the same analysis. We had a total of 264 months ( 22 years) that were split into three subperiods of four years and two of five years, as can be seen in Table 2.

The $F$-statistics indicated that the average returns were jointly equal during the five subperiods for all portfolios considered, which leads us to conclude that the proposed strategy is relatively stable through time. Furthermore, the predictions generated by our model were stable for all subperiods, given the positive risk-adjusted returns for the arbitrage portfolio (although not always statistically 
significant). In addition, the average returns for the strong fundamentals portfolio were higher than those observed for the weak fundamentals or for the market portfolios in all subperiods. The risk-adjusted returns for the strong portfolio were also higher in comparison to the weak portfolio.

Table 2

Portfolios' results: subperiod analysis

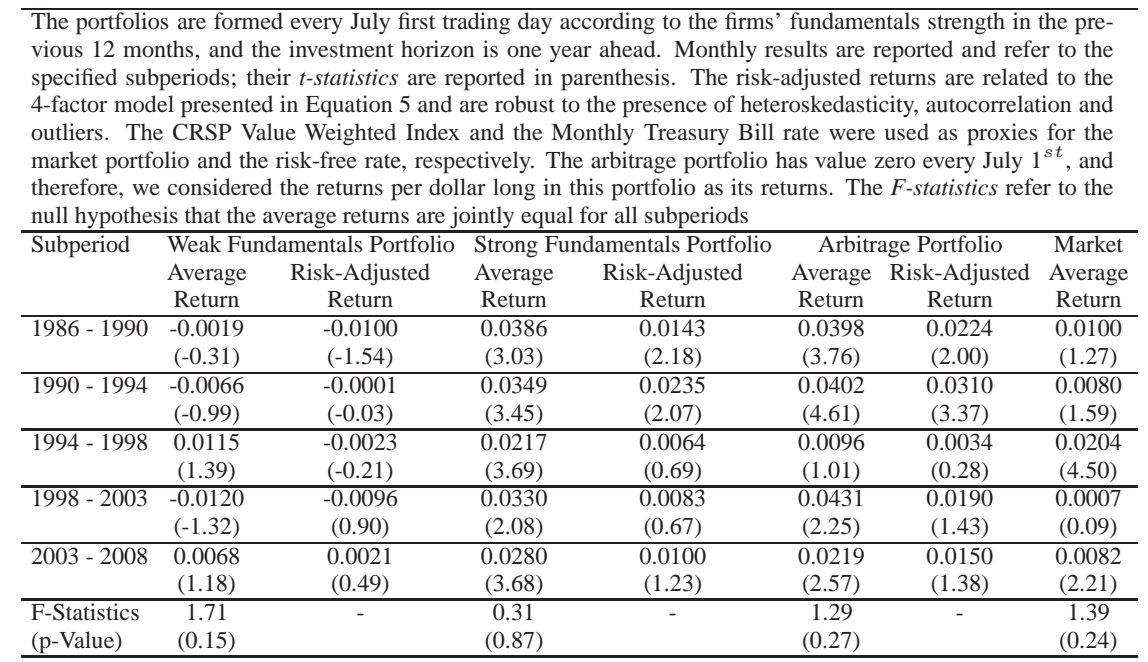

We also conducted an analysis by calendar month to verify whether seasonal effects exist in the performance of our investment methodology. This seasonal analysis can be found in Table 3. The F-statistics indicated that the average returns were not jointly equal for all calendar months for any portfolio considered, aside from the market portfolio, indicating that our strategy presented significant seasonal effects. 
Table 3

Portfolios' returns by calendar months

\begin{tabular}{|c|c|c|c|c|}
\hline \multicolumn{5}{|c|}{$\begin{array}{l}\text { The portfolios are formed every July first trading day according to the firms' fun- } \\
\text { damentals strength in the previous } 12 \text { months, and the investment horizon is one } \\
\text { year. The average monthly returns reported refer to the specified calendar months; } \\
\text { their } t \text {-statistics are reported in parenthesis. The CRSP Value Weighted Index was } \\
\text { used as a proxy for the market portfolio. The arbitrage portfolio has value zero } \\
\text { every July 1st, and therefore, we considered the returns per dollar long in this port- } \\
\text { folio as its returns. The } F \text {-statistics refer to the null hypothesis that the average } \\
\text { returns are jointly equal for all calendar months }\end{array}$} \\
\hline Calendar & Weak Fundamentals & Strong Fundamentals & Arbitrage & Market \\
\hline Month & Portfolio & Portfolio & Portfolio & \\
\hline January & $\begin{array}{c}-0.0015 \\
(-0.12)\end{array}$ & $\begin{array}{c}0.0830 \\
(3.72)\end{array}$ & $\begin{array}{c}0.0844 \\
(3.08)\end{array}$ & $\begin{array}{c}0.0164 \\
(1.72)\end{array}$ \\
\hline February & $\begin{array}{c}-0.0011 \\
(-0.12)\end{array}$ & $\begin{array}{l}0.0577 \\
(2.33)\end{array}$ & $\begin{array}{c}0.0630 \\
(1.97)\end{array}$ & $\begin{array}{c}0.0070 \\
(0.83)\end{array}$ \\
\hline March & $\begin{array}{c}-0.0150 \\
(-2.87)\end{array}$ & $\begin{array}{c}0.0465 \\
(3.86)\end{array}$ & $\begin{array}{c}0.0590 \\
(4.83)\end{array}$ & $\begin{array}{c}0.0069 \\
(0.98)\end{array}$ \\
\hline April & $\begin{array}{c}-0.0123 \\
(-1.01)\end{array}$ & $\begin{array}{c}0.0530 \\
(3.44)\end{array}$ & $\begin{array}{c}0.0617 \\
(2.92)\end{array}$ & $\begin{array}{c}0.0127 \\
(1.53)\end{array}$ \\
\hline May & $\begin{array}{c}0.0240 \\
(2.08)\end{array}$ & $\begin{array}{c}0.0500 \\
(3.17)\end{array}$ & $\begin{array}{c}0.0268 \\
(1.36)\end{array}$ & $\begin{array}{c}0.0188 \\
(2.67)\end{array}$ \\
\hline June & $\begin{array}{c}-0.0263 \\
(-2.17)\end{array}$ & $\begin{array}{c}0.0388 \\
(2.28)\end{array}$ & $\begin{array}{c}0.0596 \\
(2.38)\end{array}$ & $\begin{array}{c}0.0032 \\
(0.40)\end{array}$ \\
\hline July & $\begin{array}{c}-0.0105 \\
(-0.81)\end{array}$ & $\begin{array}{c}-0.0038 \\
(-0.28)\end{array}$ & $\begin{array}{l}0.0067 \\
(0.72)\end{array}$ & $\begin{array}{c}0.0023 \\
(0.24)\end{array}$ \\
\hline August & $\begin{array}{c}0.0081 \\
(0.58)\end{array}$ & $\begin{array}{c}0.0126 \\
(0.80)\end{array}$ & $\begin{array}{c}0.0032 \\
(0.35)\end{array}$ & $\begin{array}{c}0.0007 \\
(0.06)\end{array}$ \\
\hline September & $\begin{array}{c}-0.0049 \\
(-0.42)\end{array}$ & $\begin{array}{c}-0.0149 \\
(-1.10)\end{array}$ & $\begin{array}{c}-0.0093 \\
(-0.83)\end{array}$ & $\begin{array}{c}-0.0048 \\
(-0.48)\end{array}$ \\
\hline October & $\begin{array}{c}-0.0020 \\
(-0.15)\end{array}$ & $\begin{array}{c}0.0050 \\
(0.27)\end{array}$ & $\begin{array}{c}0.0063 \\
(0.51)\end{array}$ & $\begin{array}{c}0.0075 \\
(0.57)\end{array}$ \\
\hline November & $\begin{array}{c}0.0231 \\
(2.05)\end{array}$ & $\begin{array}{c}0.0100 \\
(0.60)\end{array}$ & $\begin{array}{c}-0.0129 \\
(-0.83)\end{array}$ & $\begin{array}{c}0.0142 \\
(1.36)\end{array}$ \\
\hline December & $\begin{array}{l}0.0103 \\
(1.63)\end{array}$ & $\begin{array}{c}0.0363 \\
(2.93)\end{array}$ & $\begin{array}{l}0.0241 \\
(1.83)\end{array}$ & $\begin{array}{c}0.0233 \\
(3.10)\end{array}$ \\
\hline $\begin{array}{l}\text { F-Statistics } \\
\text { (p-Value) }\end{array}$ & $\begin{array}{c}1.75 \\
(0.06)\end{array}$ & $\begin{array}{c}3.00 \\
(0.00)\end{array}$ & $\begin{array}{c}3.08 \\
(0.00)\end{array}$ & $\begin{array}{c}0.78 \\
(0.66)\end{array}$ \\
\hline
\end{tabular}

The arbitrage portfolio generated negative average returns for two months of analysis (September and November), but neither of those are statistically significant. For the other months, it presented positive and mostly statistically significant average returns. The strong fundamentals portfolio presented a similar pattern, but the two months of non-significant negative average returns were July and September.

On the other hand, the weak fundamentals portfolio generated mostly negative average returns, but only two of them were statistically significant (March and June); few positive average returns were generated, and of those, two were statistically significant (May and November).

In addition, the market portfolio generated only one month of negative nonsignificant average returns, but also only three months presented positive significant average returns (January, May and December).

Finally, the subperiod and calendar month analysis indicated that the strategy was stable through the years, though seasonal effects existed. However, the main characteristics of our strategy do not change significantly for different months be- 
cause none of the negative average returns for the arbitrage portfolio were statistically significant.

\subsection{Trading costs adjusted results}

The results provide evidence that our strategy (based on the arbitrage portfolio) can generate positive risk-adjusted returns, but from a practical investment perspective for institutional investors, it is important to understand whether or not the abnormal returns can be sustained after accounting for trading costs. In this context, our strategy was considered to have a turnover of $100 \% .{ }^{12}$ Berkowitz et al. (1988) estimated a one-way transaction cost of 23 basis points for institutional investors. Based on this cost, we tested our model with the adoption of a two way transaction cost of 25 b.p. per trade.

The results for the annual returns adjusted by trading costs can be found in Table 4. Annual returns for the strong fundamentals portfolio are positive for the whole sample period, while the weak fundamentals portfolio presented many negative annual returns. The weak portfolio generated a higher return compared to the strong one for only 4 of the 22 years in the sample, while the strong fundamentals portfolio beat the market for 21 out of 22 years of analysis. In addition, the arbitrage portfolio generated positive returns for 18 out of the 22 years of our analysis.

Furthermore, the average return for the strong fundamentals portfolio is $41.08 \%$ per annum, while the market portfolio and the weak fundamentals portfolio generated $10.95 \%$ and $-0.91 \%$ average annual returns, respectively. The strong fundamentals portfolio's annual risk-adjusted return was $37.70 \%$, while the weak fundamentals portfolio produced a negative risk-adjusted return of $-22.25 \%$ per annum; both are statistically significant. In addition, the arbitrage portfolio presented a positive and statistically significant average return of $40.97 \%$ and a risk-adjusted annual return of $54.85 \%$.

The results suggest that our investment approach generated positive risk-adjusted returns for the sample period even after adjusting for trading costs. It also shows some empirical evidence that supports our model, as proposed in Equation 8 , and leads to the conclusion that it is possible to profit by using a simple investment approach based on our model.

\footnotetext{
${ }^{12}$ This is a conservative assumption because not all assets are being traded each year. In fact, some of the assets remain in the portfolio for longer than one period; this leads to a turnover lower than $100 \%$.
} 
Table 4

Portfolios' annual returns adjusted by trading costs

\begin{tabular}{|c|c|c|c|c|c|}
\hline $\begin{array}{l}\text { The portfolios are form } \\
\text { ous } 12 \text { months, and the } \\
\text { subperiods. The return } \\
\text { sidered a two way tran } \\
\text { 4-factor model present } \\
\text { outliers. The CRSP Va } \\
\text { ket portfolio and the ris } \\
\text { value zero every July } 1 \\
\text { The } t \text {-statistics refer to }\end{array}$ & $\begin{array}{l}\text { ed every July } 1 \text { st trad } \\
\text { investment horizon is } \\
\text { s for the Weak, Stron } \\
\text { saction cost of } 0.25 \% \\
\text { ed in Equation } 5 \text { and } \\
\text { lue Weighted Index an } \\
\text { k-free rate, respective } \\
\text { st, and therefore, we } \\
\text { the significance of the }\end{array}$ & $\begin{array}{l}\text { ing day according to th } \\
\text { one year. The results } \\
\text { and Arbitrage portfol } \\
\text { and turnover of } 100 \% \text {. } \\
\text { re robust to the presen } \\
\text { d the Monthly Treasur } \\
\text { ly, and are not adjusted } \\
\text { considered the returns } \\
\text { average annual return }\end{array}$ & $\begin{array}{l}\text { e firms' fundamental } \\
\text { eported are annual an } \\
\text { os were adjusted by } \\
\text { The risk-adjusted re } \\
\text { e of heteroskedastici } \\
\text { Bill rate were used } \\
\text { by trading costs. The } \\
\text { er dollar long in this } \\
\text { and were reported in }\end{array}$ & $\begin{array}{l}\text { s strength } \\
\text { d refer to } \\
\text { trading c } \\
\text { turns are } \\
\text { ty, autocc } \\
\text { as proxie } \\
\text { arbitrage } \\
\text { portfolio } \\
\text { i parenthe }\end{array}$ & $\begin{array}{l}\text { n the previ- } \\
\text { he specified } \\
\text { ts that con- } \\
\text { lated to the } \\
\text { relation and } \\
\text { for the mar- } \\
\text { ortfolio has } \\
\text { its returns. } \\
\text { is }\end{array}$ \\
\hline Subperiod & $\begin{array}{c}\text { Weak Fundamentals } \\
\text { Portfolio }\end{array}$ & $\begin{array}{c}\text { Strong Fundamentals } \\
\text { Portfolio }\end{array}$ & Arbitrage Portfolio & Market & $\begin{array}{c}\text { Risk-Free } \\
\text { Rate }\end{array}$ \\
\hline $1986-1987$ & -0.0896 & 0.4572 & 0.5369 & 0.1952 & 0.0557 \\
\hline $1987-1988$ & -0.1069 & 0.4039 & 0.5010 & -0.0625 & 0.0549 \\
\hline $1988-1989$ & 0.1237 & 0.4144 & 0.2797 & 0.1878 & 0.0756 \\
\hline $1989-1990$ & -0.0677 & 0.7502 & 0.8078 & 0.1264 & 0.0822 \\
\hline $1990-1991$ & -0.3897 & 0.2222 & 0.6035 & 0.0690 & 0.0708 \\
\hline $1991-1992$ & 0.0523 & 0.9571 & 0.8943 & 0.1395 & 0.0468 \\
\hline $1992-1993$ & 0.1278 & 0.1637 & 0.0251 & 0.1618 & 0.0309 \\
\hline $1993-1994$ & -0.0641 & 0.6438 & 0.6980 & 0.0081 & 0.0306 \\
\hline $1994-1995$ & -0.1814 & 0.2177 & 0.3898 & 0.2423 & 0.0486 \\
\hline $1995-1996$ & 0.1350 & 0.6097 & 0.4637 & 0.2568 & 0.0542 \\
\hline $1996-1997$ & 0.2130 & 0.1871 & -0.0373 & 0.2875 & 0.0530 \\
\hline $1997-1998$ & 0.3958 & 0.1408 & -0.2673 & 0.2808 & 0.0510 \\
\hline $1998-1999$ & -0.2154 & 0.5395 & 0.7458 & 0.1881 & 0.0465 \\
\hline $1999-2000$ & -0.1965 & 10.017 & 11.889 & 0.1105 & 0.0514 \\
\hline $2000-2001$ & 0.1259 & 0.0316 & -0.1053 & -0.1604 & 0.0568 \\
\hline $2001-2002$ & -0.0528 & 0.3488 & 0.3917 & -0.1672 & 0.0243 \\
\hline $2002-2003$ & -0.3999 & 0.0564 & 0.4482 & 0.0236 & 0.0142 \\
\hline $2003-2004$ & 0.2723 & 0.8289 & 0.5452 & 0.2167 & 0.0090 \\
\hline $2004-2005$ & 0.2254 & 0.1685 & -0.0681 & 0.0894 & 0.0181 \\
\hline $2005-2006$ & -0.0672 & 0.3798 & 0.4371 & 0.1125 & 0.0388 \\
\hline $2006-2007$ & 0.0846 & 0.2701 & 0.1748 & 0.2131 & 0.0507 \\
\hline $2007-2008$ & -0.1259 & 0.2448 & 0.3611 & -0.1092 & 0.0337 \\
\hline Average Return & -0.0091 & 0.4108 & 0.4097 & 0.1095 & 0.0454 \\
\hline$(1986-2008)$ & $(-0.21)$ & $(6.80)$ & $(5.40)$ & $(3.76)$ & $(11.20)$ \\
\hline Risk-Adjusted Return & -0.2225 & 0.3770 & 0.5485 & - & - \\
\hline (1986-2008) & $(-5.40)$ & $(4.50)$ & $(7.49)$ & & \\
\hline
\end{tabular}

\section{Concluding Remarks}

It is possible to assess a firm's latent fundamentals strength based on the structure of past returns and a single-factor mixed effects panel data model. We argue that the unrestricted model for the structure of stock returns is given by the market variable and $N$ firm-specific latent fundamentals characteristics. Even though these characteristics are not directly observed, it is possible to value the strength of the combination of these $N$ firm-level characteristics for each stock.

In addition, a trading strategy that buys and sells stocks according to their latent fundamentals strength realized significant risk-adjusted returns for the period between July 1986 and June 2008. This result was obtained through the examination of an investment strategy that buys the stocks with the strongest latent fundamentals (the "strong fundamentals portfolio") and sells stocks with the weakest latent fundamentals (the "weak fundamentals portfolio"); hence, it is possible to explore the arbitrage opportunity originating from the differences in firm-level latent fundamentals. The portfolio created through this strategy (arbitrage portfolio) 
has a low level of market risk and a significant risk adjusted return because of its composition; it is generated by a panel data mixed effects approach.

For example, the arbitrage portfolio generated a significant average monthly return of $3.11 \%$ and a risk-adjusted return of $2.07 \%$, considering the 4-factor model proposed by Carhart (1997) and presented a market sensibility (CAPM Beta) of 0.14 .

We also provided subperiod and seasonal analyses in order to identify the strategies' specific characteristics. First, the sample period was divided into five subperiods and the analysis suggested that we cannot reject the hypothesis that the arbitrage portfolio average returns for different subperiods are jointly equal. Then, we considered the average returns per calendar month and found that the arbitrage portfolio returns differ for different months, generating mostly positive and statistically significant returns but with two months of non-significant negative returns.

To assure the strategy's practical profitability, we performed a trading cost adjusted analysis and found that the arbitrage portfolio generated a significant average annual return of $40.97 \%$ and a risk-adjusted return of $54.85 \%$ per annum. Furthermore, the strong fundamentals portfolio presented positive annual returns adjusted by costs for all of the 22 years of analysis.

Nonetheless, two limitations arise in the results of this study. The first is related to the approach used to evaluate the transaction costs, which is based on the study of Berkowitz et al. (1988), which can generate different results when considering alternative approaches. Finally, the sample period used in the study (1985-2008) does not address the global financial crisis, which may influence the robustness of our results in larger samples.

Finally, there is some empirical evidence that our model is able to profit from the differences in firm-level latent fundamentals; this allows us to infer that it is possible to estimate the firm-level latent fundamentals from the structure of past returns. These results confirm related empirical findings regarding the value premium and other anomalies, implying that some degree of predictability for stock returns exists. This paper also provides some evidence that it is possible to generate profitable strategies with a panel data approach with mixed effects. Therefore, the results provide evidence that contradicts the Efficient Market Hypothesis.

\section{References}

Acharya, Viral V., \& Pedersen, Lasse H. 2005. Asset Pricing with Liquidity Risk. Journal of Financial Economics, 77, 375-410.

Ang, Andrew, \& Bekaert, Geert. 2007. Stock Return Predictability: Is It There? The Review of Financial Studies, 20, 651-707.

Ang, Andrew, Hodrick, Robert J., Xing, Yuhang, \& Zhang, Xiaoyan. 2006. The Cross-Section of Volatility and Expected Returns. The Journal of Finance, 61, 259-299. 
Berkowitz, Stephen A., Logue, Dennis E., \& Noser, Eugene A. 1988. The Total Costs of Transactions on the NYSE. The Journal of Finance, 43, 97-112.

Binswanger, Mathias. 2004. How Important are Fundamentals?-Evidence from a Structural VAR Model for the Stock Markets in the US, Japan and Europe. Journal of International Financial Markets, 14, 185-201.

Bodie, Zvi, Kane, Alex, \& Marcus, Alan. 2001. Investments. Irwin: McGraw-Hill, New York.

Carhart, Michael. 1997. On Persistence in Mutual Fund Performance. The Journal of Finance, 52, 57-82.

Chan, Louis K. C., \& Lakonishok, Josef. 2004. Value and Growth Investing: Review and Update. Financial Analysts Journal, 58, 71-86.

Chen, Long, Petkova, Ralitsa, \& Zhang, Lu. 2008. The Expected Value Premium. Journal of Financial Economics, 87, 269-280.

Chou, Pin-Huang, Ho, Po-Hsin, \& Ko, Kuang-Cheng. 2011. Do Industries Matter in Explaining Stock Returns and Asset Pricing Anomalies? Journal of Banking \& Finance.

Cohen, Randolph B., Polk, Chirstopher, \& Vuolteenaho, Tuomo. 2009. The Price Is (Almost) Right. The Journal of Finance, 64, 2739-2782.

Croux, Christophe, Dhaene, Geert, \& Hoorelbeke, Dirk. 2004. Robust Standard Errors for Robust Estimators. Discussion Papers Series 03.16, K.U. Leuven, CES.

Elton, Edwin, Gruber, Martin J., Das, Sanjiv, \& Hlavaka, Matthew. 1993. Efficiency with Costly Information: A Reinterpretation of Evidence from Managed Portfolios. Review of Financial Studies, 6, 1-22.

Fama, Eugene, \& French, Kenneth. 1992. The Cross-Section of Expected Stock Returns. Journal of Finance, 47, 427-465.

Fama, Eugene, \& French, Kenneth. 1993. Common Risk Factors in the Returns on Stocks and Bonds. Journal of Financial Economics, 33, 3-56.

Fama, Eugene, \& French, Kenneth. 1996. Multifactor Explanations of Asset Pricing Anomalies. The Journal of Finance, 51, 55-84.

Fama, Eugene, \& French, Kenneth. 1998. Value versus Growth: The International Evidence. The Journal of Finance, 53, 1975-1999.

Fama, Eugene, \& French, Kenneth. 2004. The Capital Asset Pricing Model: Theory and Evidence. The Journal of Economic Perspectives, 18, 25-46. 
Fama, Eugene, \& French, Kenneth. 2006. The Value Premium and the CAPM. The Journal of Finance, 61, 2163-2185.

Fitzmaurice, Garrett M., Laird, Nan M., \& Ware, James H. 2004. Applied Longitudinal Analysis. Hoboken: John Wiley \& Sons.

Friend, Irwin, \& Blume, Marshall E. 1970. Measurement of Portfolio Performance under Uncertainty. American Economic Review, 60, 607-636.

Hirshleifer, David A., Hou, Kewei, \& Teoh, Siew H. 2009. Accruals, Cash Flows, and Aggregate Stock Returns. Journal of Financial Economics, 91, 389-406.

Huber, Peter J., \& Ronchetti, Elvezio. 2009. Robust Statistics. New Jersey: John Wiley and Sons.

Jagannathan, Ravi, \& McGrattan, Ellen. 1995. The CAPM Debate. Federal Reserve Bank of Minneapolis Quarterly Review, 19, 2-17.

Jegadeesh, Narasimhan, \& Titman, Sheridan. 1993. Returns to Buying Winners and Selling Losers: Implications for Stock Market Efficiency. The Journal of Finance, 48, 65-91.

Jensen, Michael, Black, Fischer, \& Scholes, Myron. 1972. The Capital Asset Pricing Model: Some Empirical Tests. Pages 79-125 of: Jensen, M. (ed), Studies in the Theory of Capital Markets. New York: Praeger Publishers.

Kang, Qiang, Liu, Qiao, \& Qi, Rong. 2010. Predicting Stock Market Returns with Aggregate Discretionary Accruals. Journal of Accounting Research, 48, $815-858$.

Lakonishok, Josef, Shleifer, Andrei, \& Vishny, Robert W. 1994. Contrarian Investment, Extrapolation, and Risk. The Journal of Finance, 49, 1541-1578.

Lintner, John. 1965. The Valuation of Risk Assets and the Selection of Risky Investments in Stock Portfolios and Capital Budgets. Review of Economics and Statistics, 47, 13-37.

Liu, Weimin. 2006. A Liquidity-Augmented Capital Asset Pricing Model. Journal of Financial Economics, 82, 631-671.

Louis, Rosmy J., \& Eldomiaty, Tarek. 2010. How Do Stock Prices Respond to Fundamental Shocks in the Case of the United States? Evidence from NASDAQ and DJIA. The Quarterly Review of Economics and Finance, 50, 310-322.

Markowitz, Harry M. 1952. Portfolio Selection. The Journal of Finance, 7, 77-91.

Mossin, Jan. 1966. Equilibrium in a Capital Asset Market. Econometrica, 34, $768-783$. 
Petkova, Ralitsa, \& Zhang, Lu. 2005. Is Value Riskier Than Growth? Journal of Financial Economics, 78, 187-202.

Ross, Stephan A. 1976. The Arbitrage Theory of Capital Asset Pricing. Journal of Economic Theory, 13, 341-360.

Rousseeuw, Peter J., \& Yohai, Victor J. 1984. Robust Regression by Means of S-Estimators. Pages 256-272 of: Franke, J., Härdle, W., \& Martin, R. D. (eds), Robust and Nonlinear Time Series. New York: Lectures Notes in Statistics.

Sharma, Vivek, Hur, Jungshik, \& Lee, Hei-Wai. 2008. Glamour versus Value: Trading Behavior of Institutions and Individual Investors. Journal of Financial Research, 31, 65-84.

Sharpe, William F. 1963. A Simplified Model of Portfolio Analysis. Management Science, 9, 277-293.

Sharpe, William F. 1964. Capital Asset Prices: A Theory of Market Equilibrium under Conditions of Risk. The Journal of Finance, 19, 425-442.

Stein, Jeremy. 2009. Presidential Address: Sophisticated Investors and Market Efficiency. The Journal of Finance, 64, 1517-1548.

Subrahmanyam, Avanidhar. 2010. The Cross-Section of Expected Stock Returns: What Have We Learnt from the Past Twenty-Five Years of Research? European Financial Management, 16, 27-42.

Yohai, Victor J. 1987. High Breakdown-Point and High Efficiency Estimates for Regression. The Annals of Statistics, 15, 642-65. 